\title{
An Analysis of how Financial Ratios of Companies in Turkey Are Affected by National Standards, and IFRS
}

\author{
Hülya Cengiz ${ }^{1}$, Alan Combs ${ }^{2}$, Martin Samy ${ }^{3}$ \\ ${ }^{1}$ Graduate School of Social Sciences, Yildiz Technical University, 34220 Istanbul, Turkey \\ ${ }^{2}$ Leeds Business School, Leeds Beckett University, City Campus, Leeds, United Kingdom LS1 3HE \\ ${ }^{3}$ Corporate Social Responsibility, Visiting Professor, Kedge Business School, Bordeaux, France; Assistant Editor, \\ Social Responsibility Journal, France
}

Correspondence: Hülya CENGIZ, PhD, Graduate School of Social Sciences, Yildiz Technical University, 34220 Istanbul, Turkey.

Received: September 18, 2017

doi:10.5539/ibr.v10n12p183
Accepted: November 7, 2017 Online Published: November 16, 2017

URL: https://doi.org/10.5539/ibr.v10n12p183

\begin{abstract}
Adoption in 2005 of IAS/IFRS by Turkish listed companies resulted in changes in classification, valuation and disclosure of financial items. This paper makes accessible to non-Turkish speakers a detailed investigation of the results from previous ratio analysis studies identified by Balsari \& Varan (Balsari \& Varan, 2014), in addition to presenting a more extensive analysis than Cengiz (Cengiz, 2014). Eight financial ratios have been analysed before and after implementation of international standards. One set of results compares the periods 2002-2003 with 2005-2006; and the other 2004 with 2005. The companies investigated are substantially the same in both analyses, but different versions of national standards are compared against international standards. Significant differences in average Book Value of Equity per Share are found after implementation of international standards for both sets of comparisons; and for one set only, at a lower confidence level, significant differences are indicated in the leverage ratio. The major contribution of the paper is the analyses of the differences during the pre and post implementation of international standards.
\end{abstract}

Keywords: financial reporting standards, financial performance, financial structure

\section{Introduction}

The records of similar accounting activities under the application of different national accounting standards cause different results in the financial statement. Adoption of international accounting standards is essentially for countries who aim towards an open market strategy. Listed companies in Turkey that have traded Borsa Istanbul (BIST) have adopted International Accounting Standards since 2005. On the other hand, listed companies were allowed voluntary adoption of IAS/IFRS in 2003 and 2004 by Capital Markets Board of Turkey.

The International Accounting Standards Board is an authority for the development and publication of International Financial Reporting Standards (IFRS), including the IFRS for Small and Medium Size Enterprises. The Board aims to develop a single set of high-quality, understandable, enforceable and globally accepted accounting standards. IFRS Standards are said to bring transparency, accountability and efficiency to financial markets around the world ("IFRS," 2017).

The Turkish accounting system comprises mainly Tax Procedure Law, General Communiqué on Accounting System Application Turkish Commercial Code and Turkish Accounting Standards. The regulatory and supervisory authority is the Capital Markets Board of Turkey (CMB) in charge of the securities markets in Turkey.

Tax Procedure Law (No.213) is the main regulation of tax accounting. It was enacted in 1961 but was amended if needed. Law requires that accounting and the related records must be kept for tax and taxable income determination (Simga-Mugan, 1995). The "General Communiqué on Accounting System Application" has been the main source of accounting application since 1994. It was enacted to accounting principles and uniform financial statements by Ministry of Finance. All companies except banks, brokerage firms and insurance companies are required to observe the guidelines stated in the communiqué (Simga-Mugan, 1995). The communiqué which contains name of accounts to be used, accounting methods, financial statements, financial statements format, principles and rules has arranged structure of accounting applications (Bilginoglu, 1996). 
Turkish Commercial Code (No.6102) has regulated the commercial life since July 2012. Turkish Commercial Code accepts Public Oversight, Accounting and Auditing Standards Authority as an authority to set and issue accounting standards. Accounting standards are voluntary for SMEs but mandatory for listed companies, banks, mutual funds, investment companies and portfolio management companies. The mandatory companies operate under the supervision of CMB.

Public Oversight, Accounting and Auditing Standards Authority was established by Decree Law ('Public Oversight, Accounting and Auditing Standards Authority's Organization and Responsibilities Decree Law,"2011) in 2011. The Authority set and issue Turkish Accounting Standards compliant with the international standards, to ensure uniformity, high quality and confidence in statutory audits, to set the auditing standards, to approve statutory auditors and audit firms and to inspect their audits, and perform public oversight in the field of statutory audits ("Public Oversight, Accounting and Auditing Standards Authority," 2016).

The first set of financial accounting standards were developed in January 1989 by the Capital Markets Board (CMB) to come into effect for fiscal years starting on or after 1 January 1989 (Communiqué, 1989). These financial accounting standards, Serial XI No.1, which control the preparation and presentation of financial statements of publicly traded companies, insurance companies, banks and brokerage firms, are comparable with international accounting standards (Simga-Mugan, 1995). Another set of financial standards, Serial: XI, No: 21, was issued to apply after 2003 by CMB (Communiqué, 2001).

Capital Markets Board of Turkey issued Serial: XI, No: 25 in 2003 (Communiqué, 2003) for the listed companies on stock exchange. The first Turkish Accounting Standards was issued by the Capital Markets Board. Mainly these standards were translation form of international standards. Listed companies started mandatory application of IAS / IFRS from 1 January 2005. Voluntary application of international standards was possible for financial reports from 31 December 2003.

The Turkish Accounting Standards Board was authorized to publish the financial reporting standards instead of Capital Markets Board in 2008. (Communiqué, 2008). The board issued Turkish Accounting Standards and Turkish Financial Reporting Standards. These standards translated from IAS/IFRS for Turkish companies.

The Public Oversight, Accounting and Auditing Standards Authority is an authority to set and issue Turkish Accounting Standards in compliance with the international standards in order to ensure relevance, transparency, reliability, understandability, comparability and consistency of financial statements of the parties who are liable to keep books in accordance with the laws they are subject to ("Public Oversight, Accounting and Auditing Standards Authority's Organization and Responsibilities Decree Law," 2011). Before this authority, Capital Markets Board of Turkey and The Turkish Accounting Standards Board were the authority to set and issue the standards.

The Public Oversight, Accounting and Auditing Standards Authority was established ('Public Oversight, Accounting and Auditing Standards Authority's Organization and Responsibilities Decree Law," 2011) instead of the Turkish Accounting Standards Board. Standards Board transferred all legally enforceable rights to Public Oversight, Accounting and Auditing Standards Authority. The authority issued Framework, 15 TFRS, 28 TMS and, 25 implementation guidance.

\section{Literature Review}

Lantto and Sahlström (Lantto \& Sahlström, 2009) investigated changes in accounting standards and financial ratios after conversion from domestic accounting standards (DAS) to IFRS for listed companies on the Helsinki Stock Exchange in Finland. They used financial ratios which were current ratio, equity ratio, gearing ratio, operating profit margin, price to earnings ratio, quick ratio, return on equity and, return on invested capital. The adoption of IFRS changed the profitability ratios, gearing ratio, quick ratios, equity ratios and price/earnings ratio.

Callao et al. (Callao, Jarne, \& Laínez, 2007) investigated significant differences in key financial ratios under the basis of Spanish and international accounting standards. Listed companies, was used for analyse. The results of the study indicate that the financial ratios of listed Spanish companies, IBEX 35, differed significantly when IFRS rather DAS were applied in the preparation of financial information for the first half of 2004. These were cash ratio, solvency and indebtedness, return on assets per operating income, return on equity per ordinary income and net income.

Goodwin et al. (Goodwin, Ahmed, \& Heaney, 2008) examined the effect of Australian equivalents to IFRS on the accounts and accounting quality changes of financial ratios under DAS and IFRS for 1,065 listed firms. They found that under IFRS, mean liabilities increase; mean equity decreases; there were more decreases to earnings 
than increases; and the leverage ratio. Also application of IFRS was increased total liabilities, decreased equity and more firms had earnings.

Balsari and Varan (Balsari \& Varan, 2014) identify studies evaluating the effect of IAS / IFRS adoption on Turkish companies, with the following using ratio analysis:

Celik et al. (Celik, Aygoren, \& Uyar, 2007) analysed 43 companies to specify the impact of IFRS adoption in Turkey. The financial statements of these companies for the year 2004 were prepared using domestic Turkish standards, while the 2004 comparatives in the 2005 financial statements were restated using IFRS. Thus application of differing standards to the same underlying transaction data could be evaluated. The fixed assets equity ratio, debt-equity ratio and long term debt ratio, were statistically significantly different under DAS and IFRS. Alkan and Doğan (Alkan \& Doğan, 2012) calculated ratios before and after implementation of IFRS firstly over the period of transition 2004-2005, and secondly for the long term between 2000-2009. Significant differences were found in Long Term Debt Ratio and Total Assets to Equity ratio in the transitional period. For the long term period significant differences were found in Current Ratio, Acid Test Ratio and Asset Turnover Ratio.

Terzi et al. (Terzi, Oktem, \& Sen, 2013) investigated companies listed on the Borsa Istanbul (BIST) operating in the manufacturing sector. Significant differences were identified in Cash Ratio, Receivables Turnover, Asset Turnover, Fixed Asset Turnover, Equity Turnover, Short Term Liabilities to Total Debts and Short Term Liabilities to Total Assets. Sub- sectors did not all completely reflect these differences, except for the Cash Ratio which was significantly different across all sub-sectors.

Cengiz (Cengiz, 2014) tested differences of financial ratios under DAS and IFRS. For this aim fifteen financial ratios were analysed for listed companies in Istanbul Stock exchange for the period from 1997 to 2003 when DAS was in use; for the period from 2005 to 2010 when IFRS was in use. In the analysis a statistical relationship was found for return on equity, return on assets, ratio of assets to equity, ratio of liabilities and equity, ratio of liabilities to assets for different periods under DAS and IFRS.

The present paper contributes to the literature on results of international accounting standards application by testing mandatory and voluntary application. Financial ratios were analysed for transition period and short term period before and after international standards.

\section{Methodology}

The paper was conducted to investigate whether financial ratios are statistically changed after conversion from National Standards (NS) to IFRS. For this, financial ratios were calculated from financial statements which were prepared according to NS and IFRS. The companies investigated were those listed on the BIST, excluding the banking sector. Two sets of comparison were made. The first set compares financial statements under the national accounting standards of Turkey Serial XI, No: 1 to IFRS, where results were compared for 2002-2003 against 2005-2006. The second set compared financial statements under the national accounting standards of Turkey Serial XI, No: 21 to IFRS, where results are compared for 2004 against 2005.

Eight different ratios of companies were chosen to examine the impact of international standards adoption on measures of profitability, financial structure and value of companies:

- Book value per share (BVPS)

- Pre-tax income margin,

- Return on equity,

- Return on fixed assets,

- Return on assets,

- The ratio of assets to equity,

- The ratio of debts to equity,

- Leverage ratio (total debts /total assets).

These six ratio was used in previous study (Cengiz, 2014) that were return on equity, return on fixed assets, return on assets, the ratio of assets to equity, the ratio of debts to equity and leverage ratio was found significant relation except for return on fixed assets.

Paired sample $t$-test was used in the analyse to determine whether two groups financial ratio were significantly different from NS to IFRS 


\section{Data}

Listed companies on BIST reported financial statements according to set of accounting standards, Serial XI No:1, for the analyse period of 2002-2003. Another set of accounting standards were in use in 2004. On the other hand voluntary adoption of IAS/IFRS was possible the years of 2003 and 2004 but the adaption of intentional standards was mandatory in 2005 . In the analyse companies were separated according to both set of accounting standards and years in Table 1.

Table 1. Accounting Standards in Turkey (2002-2006)

\begin{tabular}{|c|c|c|c|c|c|}
\hline \multirow{2}{*}{ Rules } & \multicolumn{5}{|c|}{ Years } \\
\hline & 2002 & 2003 & 2004 & 2005 & 2006 \\
\hline National Standard (Serial: XI, No:1) & $\mathrm{x}$ & $\mathrm{x}$ & & & \\
\hline National Standard (Serial: XI, No:21) & & & $\mathrm{X}$ & & \\
\hline IFRS/IAS (Serial: XI, No:25) & & $\mathrm{x}$ & $\mathrm{X}$ & $\mathrm{x}$ & $\mathrm{x}$ \\
\hline
\end{tabular}

4.1 First Group Data - National Accounting Standards (Serial: XI, No:1) against IAS / IFRS

Listed companies on the stock exchange were allowed to voluntarily choose IFRS instead of national standards for the years of 2003 and 2004. For the first group data, national standard period (2002-2003) and international standard period (2005-2006) are compared. Financial statements of 2004 are not included, because in this year companies reported their financial reports according to another version of national standards. Financial ratios of 42 companies listed on stock exchange (BIST) are calculated for these years except for banking sector.

Descriptive statistics that are standard deviation, minimum and maximum values are showed Table 2.

Table 2. Summary Statistics

Panel A: Summary Statistics when NS were applied

\begin{tabular}{|c|c|c|c|}
\hline Financial Ratio & Std Dev & Min & Max \\
\hline BVPS & 0.22 & -0.01 & 1.43 \\
\hline Pretax Income Margin & 120.35 & -100.92 & 775.25 \\
\hline Return on Equity & 99.25 & -280.81 & 563.93 \\
\hline Return on Fixed Assets & 32.80 & -100.01 & 100.64 \\
\hline Return on Assets & 8.11 & -17.20 & 19.15 \\
\hline Assets/Equity & 20.53 & -123.53 & 5.99 \\
\hline Debts/Equity & 17.55 & -103.71 & 3.76 \\
\hline Leverage Ratio & 0.36 & 0.02 & 2.17 \\
\hline \multicolumn{4}{|c|}{ Panel B: Summary Statistics when IFRS/IAS were applied } \\
\hline Financial Ratio & Std Dev & Min & Max \\
\hline BVPS & 17.75 & 0.09 & 90.04 \\
\hline Pretax Income Margin & 21.71 & -19.79 & 84.41 \\
\hline Return on Equity & 32.76 & -62.07 & 195.33 \\
\hline Return on Fixed Assets & 15.12 & -19.08 & 50.61 \\
\hline Return on Assets & 7.66 & -10.58 & 25.64 \\
\hline Assets/Equity & 9.68 & -49.62 & 8.23 \\
\hline Debt/Equity & 9.30 & -47.97 & 7.23 \\
\hline Leverage Ratio & 0.21 & 0.03 & 0.94 \\
\hline \multicolumn{4}{|c|}{ Panel C: Differences between NS and IFRS/IAS } \\
\hline Financial Ratio & Std Dev & Minimum & Maximum \\
\hline BVPS & 17.76 & -0.01 & 89.98 \\
\hline Pretax Income Margin & 120.23 & -764.35 & 92.73 \\
\hline Return on Equity & 79.50 & -368.60 & 311.06 \\
\hline Return on Fixed Assets & 31.85 & -90.90 & 101.89 \\
\hline Return on Assets & 9.19 & -21.21 & 25.45 \\
\hline Assets/Equity & 13.58 & -14.83 & 73.91 \\
\hline Debts/Equity & 11.31 & -14.83 & 55.74 \\
\hline Leverage Ratio & 0.25 & -1.24 & 0.39 \\
\hline
\end{tabular}

Financial ratios of 45 same companies listed on stock exchange (BIST) are calculated for the years of 2004 and 2005 except for banking sector. For the year of 2004, companies which were not adopted IFRS were included in the analysis. However for the year 2005, companies which were adopted IFRS were included in the analysis.

In the analysis, results of financial performance were tested whether the mean difference between two sets of observations is zero. 


\section{Results}

\subsection{Results 1 - National Accounting Standards (Serial: XI, No:1) against IAS / IFRS}

Financial results of national accounting standards and international accounting standards are tested for the period 2002-2003 and 2005-2006. Eight financial ratios are used to measure financial results. Summary of paired sample test and financial ratios are showed Table 3.

For the test paired sample $t$ test are conducted to find mean differences

Table 3. Summary of Paired Samples Statistics

\begin{tabular}{lllll}
\hline Financial Ratios & Standards & Mean & N & Std. Deviation \\
\hline \multirow{2}{*}{ BVPS } & IFRS & 11.46 & 42 & 17.97 \\
& NS & 0.05 & 42 & 0.22 \\
\hline \multirow{2}{*}{ Pretax Income Margin } & IFRS & 11.91 & 42 & 21.98 \\
& NS & 23.50 & 42 & 121.81 \\
\hline \multirow{2}{*}{ Return on Equity } & IFRS & 12.28 & 42 & 33.16 \\
& NS & 17.91 & 42 & 100.46 \\
\multirow{2}{*}{ Return on Fixed Assets } & IFRS & 10.89 & 42 & 15.30 \\
\multirow{2}{*}{ Return on Assets } & NS & 16.56 & 42 & 33.20 \\
\hline \multirow{2}{*}{ Assets / Equity } & IFRS & 5.27 & 42 & 7.75 \\
\multirow{2}{*}{ Debts / Equity } & NS & 4.82 & 42 & 8.21 \\
\hline \multirow{2}{*}{ Leverage Ratio } & IFRS & -0.01 & 42 & 9.80 \\
& NS & -2.64 & 42 & 20.78 \\
\hline
\end{tabular}

Paired sample correlations are showed below at Table 4. As a results, return on equity, the ratio of total assets to equity, the ratio of total debts to equity and leverage ratio have correlation (confidence level - 99\%); return on assets has correlation (confidence level - 95\%).

Table 4. Paired Samples Correlations

\begin{tabular}{|c|c|c|c|c|}
\hline Financial Ratios & Standards & $\mathrm{N}$ & Correlation & Sig. \\
\hline BVPS & $\begin{array}{l}\text { IFRS } \\
\text { NS }\end{array}$ & 42 & -0.03 & 0.85 \\
\hline Pretax Income Margin & $\begin{array}{l}\text { IFRS } \\
\text { NS } \\
\end{array}$ & 42 & 0.01 & 0.55 \\
\hline Return on Equity & $\begin{array}{l}\text { IFRS } \\
\text { NS }\end{array}$ & 42 & 0.71 & 0.00 \\
\hline Return on Fixed Assets & $\begin{array}{l}\text { IFRS } \\
\text { NS }\end{array}$ & 42 & 0.30 & 0.06 \\
\hline Return on Assets & $\begin{array}{l}\text { IFRS } \\
\text { NS } \\
\end{array}$ & 42 & 0.32 & 0.04 \\
\hline Assets / Equity & $\begin{array}{l}\text { IFRS } \\
\text { NS }\end{array}$ & 42 & 0.83 & 0.00 \\
\hline Debts / Equity & $\begin{array}{l}\text { IFRS } \\
\text { NS } \\
\end{array}$ & 42 & 0.82 & 0.00 \\
\hline Leverage Ratio & $\begin{array}{l}\text { IFRS } \\
\text { NS }\end{array}$ & 42 & 0.74 & 0.00 \\
\hline
\end{tabular}

Table 5. Paired Samples t Test

\begin{tabular}{lllc}
\hline Financial Ratios & Mean & Std. Deviation & $\begin{array}{c}\text { Sig. } \\
(2 \text {-tailed })\end{array}$ \\
\hline BVPS & 11.41 & 17.98 & 0.00 \\
Pretax Income Margin & -11.59 & 121.69 & 0.54 \\
Return on Equity & -5.63 & 80.46 & 0.65 \\
Return on Fixed Assets & -5.67 & 32.23 & 0.26 \\
Return on Assets & 0.45 & 9.31 & 0.76 \\
Assets / Equity & 2.63 & 13.75 & 0.22 \\
Debts / Equity & 2.08 & 11.45 & 0.25 \\
Leverage Ratio & -0.08 & 0.25 & 0.05 \\
\hline
\end{tabular}

Averages and value of significance are showed at Table 6 according to accounting standards (NS, IFRS). When NS was in use BVPS at 11.46; when IFRS was in use BVPS at 0.05 (confidence level - 99\%). When NS was in use debt to total assets at 0.46 ; when IFRS was in use debt to total assets at 0.38 (confidence level - 95\%). 
Table 6. Averages and Significance

\begin{tabular}{|c|c|c|c|c|c|c|}
\hline & IFRS & NS & DIFFERENCE & $\mathrm{t}$ & $\mathrm{df}$ & $\begin{array}{l}\text { Sig } \\
\text { (2-ailed) }\end{array}$ \\
\hline BVPS & 11.46 & 0.05 & 23.45 & 4.11 & 41 & 0.00 \\
\hline Pretax Income Margin & 11.91 & 23.50 & -5.59 & -0.62 & 41 & 0.54 \\
\hline Return on Equity & 12.28 & 17.91 & -1.35 & -0.45 & 41 & 0.65 \\
\hline Return on Fixed Assets & 10.89 & 16.56 & -11.74 & -1.14 & 41 & 0.26 \\
\hline Return on Assets & 5.27 & 4.82 & -7.46 & 0.31 & 41 & 0.76 \\
\hline Assets/Equity & -0.01 & -2.64 & -0.55 & 1.24 & 41 & 0.22 \\
\hline Debts /Equity & -1.11 & -3.19 & 3.65 & 1.18 & 41 & 0.25 \\
\hline Leverage Ratio & 0.38 & 0.46 & -0.46 & -1.99 & 41 & 0.05 \\
\hline
\end{tabular}

5.2 Results 2 - National Standard (Serial: XI, No:21) against IAS / IFRS

Summary of paired sample statistics are showed in Table 7.

Table 7. Summary of Paired Samples Statistics

\begin{tabular}{lllll}
\hline Financial Ratios & Standards & Mean & N & Std. Deviation \\
\hline \multirow{2}{*}{ BVPS } & IFRS & 11.34 & 45 & 16.92 \\
& NS & 0.49 & 45 & 2.74 \\
\hline \multirow{2}{*}{ Pretax Income Margin } & IFRS & 14.55 & 45 & 25.27 \\
& NS & 28.04 & 45 & 90.35 \\
\hline \multirow{2}{*}{ Return on Equity } & IFRS & 18.57 & 45 & 59.31 \\
& NS & 10.45 & 45 & 58.64 \\
\hline \multirow{2}{*}{ Return on Fixed Assets } & IFRS & 9.96 & 45 & 14.35 \\
\multirow{2}{*}{ Return on Assets } & NS & 16.23 & 45 & 46.62 \\
\hline \multirow{2}{*}{ Assets / Equity } & IFRS & 4.77 & 45 & 7.04 \\
\multirow{2}{*}{ Debts / Equity } & NS & 4.81 & 45 & 7.98 \\
\hline \multirow{2}{*}{ Leverage Ratio } & IFRS & -2.20 & 45 & 21.28 \\
& NS & 3.07 & 45 & 4.37 \\
\hline Paired sample & IFRS & -3.22 & 45 & 20.46 \\
& NS & 1.84 & 45 & 4.05 \\
\hline
\end{tabular}

Paired sample correlations are showed below at Table 8. As a results, pre-tax income margin, return on equity, return on fixed assets, ratio of total assets to equity, ratio of total debts to equity, leverage ratio have correlation (confidence level-99\%).

Table 8. Paired Samples Correlations

\begin{tabular}{llll}
\hline Financial Ratios & N & Correlation & Sig. \\
\hline BVPS & 45 & -0.099 & 0.518 \\
Pretax Income Margin & 45 & 0.383 & 0.010 \\
Return on Equity & 45 & -0.556 & 0.000 \\
Return on Fixed Assets & 45 & 0.346 & 0.020 \\
Return on Assets & 45 & 0.199 & 0.190 \\
Assets / Equity & 45 & -0.856 & 0.000 \\
Debts / Equity & 45 & -0.882 & 0.000 \\
Leverage Ratio & 45 & 0.915 & 0.000 \\
\hline
\end{tabular}

Results of Paired Samples t Test, Book Value of Equity per Share are statistically significant differences at 99\% confidence level (Table9).

Table 9. Paired Samples t Test

\begin{tabular}{llll}
\hline Financial Ratios & Mean & Std. Deviation & $\begin{array}{l}\text { Sig. } \\
(2 \text {-tailed) }\end{array}$ \\
\hline BVPS & 10.850 & 17.401 & 0.000 \\
Pretax Income Margin & -13.492 & 83.994 & 0.287 \\
Return on Equity & 8.118 & 104.031 & 0.603 \\
Return on Fixed Assets & -6.274 & 43.773 & 0.342 \\
Return on Assets & -0.042 & 9.530 & 0.977 \\
Assets / Equity & -5.274 & 25.126 & 0.166 \\
Debts / Equity & -5.062 & 24.106 & 0.166 \\
Leverage Ratio & -0.004 & 0.100 & 0.789 \\
\hline
\end{tabular}

Averages and value of significance are showed at Table 10 according to accounting standards (NS, IFRS). When NS was in use BVPS at 11.34; when IFRS was in use BVPS at 0.49 (confidence level - 99\%). 
Table 10. Averages and Significance

\begin{tabular}{llll}
\hline Financial Ratios & IFRS & NS & Sig. (2-tailed) \\
\hline BVPS & 11.34 & 0.49 & 0.00 \\
Pretax Income Margin & 14.55 & 28.04 & 0.29 \\
Return on Equity & 18.57 & 10.45 & 0.60 \\
Return on Fixed Assets & 9.96 & 16.23 & 0.34 \\
Return on Assets & 4.77 & 4.81 & 0.98 \\
Assets / Equity & -2.20 & 3.07 & 0.17 \\
Debts / Equity & -3.22 & 1.84 & 0.17 \\
Leverage Ratio & 0.41 & 0.42 & 0.79 \\
\hline
\end{tabular}

When the previous studies were analysed, recurrent themes emerge, but without complete consistency.

Celik et al. and, Alkan and Doğan (Alkan \& Doğan, 2012; Celik, et al., 2007) (for transitional comparisons only) and Terzi et al. (Terzi, et al., 2013) all identify some significant difference in long term debt, if it is compared to one or another statement of financial position values such as equity, fixed assets or short term debts. However, Alkan and Doğan (2012) do not find a significant relationship in the Long Term Debt Ratio in the long term comparison.

Asset turnover is found significantly different by Alkan and Doğan (Alkan \& Doğan, 2012) (for long term comparisons only) and by Terzi et al. (Terzi, et al., 2013) in the manufacturing sector. However, Celik et al. and Alkan and Doğan (Alkan \& Doğan, 2012; Celik, et al., 2007) (for transitional comparisons) do not find a significant difference.

The findings of this study are that Book Value Per Share is significantly different between IFRS and national standards application for both sets of comparison investigated, at a confidence level of $99 \%$. Further, for the comparison of results produced using national standards Serial: XI, No:1 against IAS / IFRS the leverage ratio is also significantly different, at a confidence level of $90 \%$. However, for the comparison of results produced using national standards Serial: XI, No: 21 against IAS / IFRS a significant difference was not found in the leverage ratio.

\section{Summary and Conclusions}

With the use of international financial reporting standards in listed companies having been made mandatory in Turkey, together with other EU countries, since 2005, there may be said to be use of a common language in accounting. Financial ratios of listed companies on Turkish stock exchange (BIST) are evaluated for the transition period of International Financial Reporting Standards. To evaluate this period paired sample t-test is conducted. The results of the study, there is statistically significant difference for book value of equity per share.

This suggests that while financial statements remain internally consistent a shift of value, or a shift in the number of shares, has occurred in absolute terms. Although not tested for, it seems unlikely that there would be a change in the number of shares across the whole of the companies surveyed.

At a lower $90 \%$ confidence level, and for one only of the two groups of comparisons, significant difference was also indicated for the leverage ratio. This tends to support findings from the other ratio analyses of a significant difference in long term debt when compared to other statement of financial position elements (Alkan \& Doğan, 2012; Celik, et al., 2007; Terzi, et al., 2013), although this finding was not universal (Alkan \& Doğan, 2012).

Taking the two findings above together, the significant changes in gearing reflected in changes in assets and liabilities reported in other studies, may be seen to be reflected in the significant change in the absolute value of equity measured using book values.

\section{References}

Alkan, G. İ., \& Doğan, O. (2012). Uluslararası Finansal Raporlama Standartları'nın Finansal Rasyolara Kısa ve Uzun Dönemli Etkileri: İMKB'de Bir Araştırma. Muhasebe ve Finansman Dergisi, Nisan, 87-100.

Balsari, C. K., \& Varan, S. (2014). IFRS Implementation and Studies in Turkey. Accounting and Management Information Systems, 13(2), 373-399.

Bilginoglu, F. (1996). Türk Muhasebe Hukuku'nun Kavramsal Çerçevesi. Sosyal Bilimler Dergisi, 2-3.

Callao, S., Jarne, J. I., \& Laínez, J. A. (2007). Adoption of IFRS in Spain: Effect on the comparability and relevance of financial reporting. Journal of International Accounting, Auditing and Taxation, 16(2), 148-178. https://doi.org/10.1016/j.intaccaudtax.2007.06.002

Celik, M., Aygoren, H., \& Uyar, S. (2007). The impact of international financial reporting standards on financial statements and financial ratios. Paper presented at the The Balkan Countries 1st Conference on Accounting 
and Auditing, Edirne.

Cengiz, H. (2014). Effects of International Financial Reporting Standards Application on Financial Ratios in Turkey. International Journal of Management Economics and Business, 10(21), 163-177. https://doi.org/10.11122/ijmeb.2014.10.21.444

Communiqué. (1989). "Serial: XI, No: 1 on Rules and Principles Regarding the Financial Statements and Reports in Capital Markets" Capital Market Board, Official Gazette of Republic of Turkey (No.20064).

Communiqué. (2001). "Serial: XI, No: 21 on Rules and Principles Regarding Consolidated Financial Statements and Accounting for Investments in Associates in Capital Markets". Capital Market Board, Official Gazette of Republic of Turkey (No.24582).

Communiqué. (2003). "Serial: XI, No: 25 on Accounting Standards in Capital Markets". Capital Market Board, Official Gazette of Republic of Turkey (No.25290).

Communiqué. (2008). "Serial: XI, No: 29 on Principles for the Financial Reporting in Capital Markets". Capital Market Board, Official Gazette of Republic of Turkey (No.26842).

Goodwin, J., Ahmed, K., \& Heaney, R. (2008). The effects of International Financial Reporting Standards on the accounts and accounting quality of Australian firms: A retrospective study. Journal of Contemporary Accounting \& Economics, 4(2), 89-119. https://doi.org/10.1016/S1815-5669(10)70031-X

IFRS. (2017). from http://www.ifrs.org accessed on 09/10/2017

Lantto, A. M., \& Sahlström, P. (2009). Impact of International Financial Reporting Standard adoption on key financial ratios. Accounting \& Finance, 49(2), 341-361. https://doi.org/10.1111/j.1467-629X.2008.00283.x

Public Oversight, Accounting and Auditing Standards Authority. (2016). from http://www.kgk.gov.tr/ accessed on 18.01.2016

Public Oversight, Accounting and Auditing Standards Authority's Organization and Responsibilities Decree Law. (2011). Official Gazette of Republic of Turkey, 28103.

Simga-Mugan, C. (1995). Accounting in Turkey. European Accounting Review, 4(2), 351-371. https://doi.org/10.1080/09638189500000020

Terzi, S., Oktem, R., \& Sen, I. K. (2013). Impact of Adopting International Financial Reporting Standards: Empirical Evidence from Turkey. International Business Research, 6(4), 55. https://doi.org/10.5539/ibr.v6n4p55

\section{Copyrights}

Copyright for this article is retained by the author(s), with first publication rights granted to the journal.

This is an open-access article distributed under the terms and conditions of the Creative Commons Attribution license (http://creativecommons.org/licenses/by/4.0/). 